\title{
Calculation and analysis of acid dew-point temperature in coal-fired boi- ler gas
}

\author{
M.T. Cheng ${ }^{1} \&$ T.H. Zeng ${ }^{1}$ \\ ${ }^{1}$ Electric Power Research Institute of Guangdong Power Grid Co.,Ltd., Guangzhou, Guangdong, \\ China
}

KEYWORD: Coal-fired boiler, Gas, Acid dew-point temperature

ABSTRACT: The current calculation method of the acid dew-point temperature of the flue gas is multifarious, and many formulas even exist obvious errors. In this paper, the representative method is used to calculate the acid dew-point temperature of the flue gas, and the Influence factors of the acid dew-point temperature are analyzed. Finally, the optimum calculation method is put forward, and the influence of main equipment to acid dew-point temperature is analyzed, and the measures of reducing the temperature of acid dew-point are put forward.

\section{INTRODUCTION}

China's most thermal power stations use coal as fuel. The composition of coal contains a certain amount of sulfur (S), in the process of coal combustion, about $90 \%$ of the $\mathrm{S}$ will be converted to $\mathrm{SO}_{2}[1]$. Part of $\mathrm{SO}_{2}$ will be further oxidized to $\mathrm{SO}_{3}$ in the catalytic role of $\mathrm{Fe}_{2} \mathrm{O}_{3}$ and $\mathrm{V}_{2} \mathrm{O}_{5}$ [2]. $\mathrm{SO}_{3}$ and the water vapor in the flue gas combine to form the sulfuric acid steam, the condensation temperature of the sulfuric acid vapor in the flue gas is called the acid dew-point temperature. When the flue gas temperature is lower than the acid dew-point temperature, the dilute sulfuric acid vapor is partially condensed on the heating surface, resulting in low temperature corrosion.

There are many factors that affect the dew-point temperature of the flue gas, such as ash and sulfur content in coal, the content of water vapor in the flue gas and so on. In the flue gas flow, any equipment which has the effect on these factors can cause the change of the acid dew-point temperature indirectly, such as the denitrification, air heater, electric dust collector, etc. Therefore, the acid dew-point temperature of the flue gas is not a constant value at different intervals. It is very important to calculate the acid dew-point temperature of the flue gas accurately for the design and corrosion protection of the equipment.

\section{Getting started Comparative study of different acid dew-point temperature calculation me- thods}

There is no unified and standard method for the calculation of acid dew-point temperature at present. For the sake of comparison, this paper selected two representative calculation methods, method A based on "boiler thermal calculation standard method", This method mainly based on coal composition and calorific value analysis; method B based on the formula of A.G.Okkes calculation, this formula is derived to test data, formula comprehensive considering the effect of $\mathrm{SO}_{3}$ and $\mathrm{H} 2 \mathrm{O}$ content to the acid dew-point temperature.

Method A: based on the standard method of boiler unit heat calculation

The formula for calculating the dew-point temperature is described as follows:

$t_{p}=t_{\text {KoN }}+125 \sqrt[3]{S^{n}} / 1.05^{\alpha_{y} H^{A^{n}}}$

There:

$t_{p} \_$Flue gas acid dew-point temperature;

$t_{K O N}$ _ Condensation temperature of water vapor in flue gas;

$S^{n} \_$Converted sulfur in coal;

$A^{n} \_$Converted ash in coal; 
$\alpha_{y} H$ Fly ash for fuel ash ratio 。

The method A has the advantage of convenient to calculation, and the required data can be easily obtained. So it is easy to calculate the dew-point temperature of the flue gas. The converted ash are considered in the formula, it is reasonable, because the carbonate has self-desulfurization effect in the ash, the disadvantage is unable to assess the influence of the conversion of $\mathrm{SO}_{2}$ to $\mathrm{SO}_{3}$ on the acid dew-point temperature.

Method B: based on the formula of A. G. Okkes

The formula of A. G. Okkes is described as follows:

$$
\begin{aligned}
& t_{\text {sld }}=10.8809+27.61 \mathrm{~g} p_{\mathrm{H}_{2} \mathrm{O}} \\
& +10.831 \mathrm{~g} p_{\mathrm{SO}_{3}} \\
& +1.06\left(1 \mathrm{~g} p_{\mathrm{SO}_{3}}+2.9943\right)^{2.19}
\end{aligned}
$$

There:

$t_{\text {sld }}$ Flue gas acid dew-point temperature;

$p_{\mathrm{H}_{2} \mathrm{O}} \_$Partial pressure of water vapor in flue gas;

$p_{\mathrm{SO}_{3}}$ __ Partial pressure of $\mathrm{SO}_{3}$ gas in flue gas;

This formula considers the effect of water vapor and $\mathrm{SO}_{3}$ content in flue gas on acid dew-point temperature, but because of the complexity of test of $\mathrm{SO}_{3}$ content, its application has been limited.

\section{Calculation and analysis of acid dew-point temperature.}

Taking a 600MW boiler as an example, the acid dew-point temperature of the flue gas flow is tested. Boiler is subcritical a reheat forced circulation drum boiler, the single chamber n-shaped open layout and full suspension steel frame structure, solid state slag. Desulfurization using limestone-gypsum wet desulphurization process, equipped with GGH system. Coal quality parameters are shown in table 1.

Table 1. Coal Composition Analysis Results

\begin{tabular}{llll}
\hline Component & Symbol & Unit & data \\
\hline $\mathrm{C}$ & Car & $\%$ & 61.18 \\
$\mathrm{H}$ & $\mathrm{Har}$ & $\%$ & 3.38 \\
$\mathrm{O}$ & Oar & $\%$ & 9.99 \\
$\mathrm{~N}$ & $\mathrm{Nar}$ & $\%$ & 0.79 \\
$\mathrm{~S}$ & $\mathrm{Sar}$ & $\%$ & 0.50 \\
$\mathrm{H} 20$ & $\mathrm{mf}$ & $\%$ & 16.7 \\
Ash & $\mathrm{A}$ & $\%$ & 7.58 \\
Low calorific value & Qnet.ar & $\mathrm{kJ} / \mathrm{kg}$ & 22840 \\
\hline
\end{tabular}

In order to compare the acid dew-point temperature in different parts of the boiler flue gas flow, the results are shown in Table 2.

Method A only considers the content of ash, sulfur and water vapor in the calculation, and does not take into account the effect of $\mathrm{SO}_{3}$ content on the flue gas acid dew-point. In the section of inlet SCR to the GGH, the content of water vapor in the flue gas is almost unchanged. Therefore, the acid dew-point temperature is unchanged at $85.38^{\circ} \mathrm{C}$, which is obviously not in accord with the actual situation. After the flue gas is absorbed by the FGD, the humidity in the flue gas is close to the saturated state, and the aid dew-point temperature of the flue gas is raised to an increase of $16.64^{\circ} \mathrm{C}$ to $102.02^{\circ} \mathrm{C}$. 
Table 2 Calculation results of dew-point temperature of flue gas

\begin{tabular}{llllllll}
\hline Item & Unit & $\begin{array}{l}\text { SCR } \\
\text { inlet }\end{array}$ & $\begin{array}{l}\text { SCR } \\
\text { outlet }\end{array}$ & $\begin{array}{l}\text { Air heater } \\
\text { outlet }\end{array}$ & $\begin{array}{l}\text { Raw gas } \\
\text { GGH out- } \\
\text { let }\end{array}$ & $\begin{array}{l}\text { FGD } \\
\text { outlet }\end{array}$ & $\begin{array}{l}\text { Clean gas } \\
\text { GGH out- } \\
\text { let }\end{array}$ \\
\hline $\mathrm{SO}_{3}$ content & $\mu \mathrm{mol} / \mathrm{mol}$ & 3.3 & 5.6 & 4.9 & 4.2 & 2.5 & 2.3 \\
$\mathrm{H}_{2} \mathrm{O}$ content & $\%$ & 5.5 & 5.5 & 5.5 & 5.5 & 11.8 & 11.6 \\
Gas pressure & $\mathrm{Pa}$ & 100872 & 100521 & 98500 & 103925 & 101840 & 101450 \\
Gas temperature & ${ }^{\circ} \mathrm{C}$ & 350.7 & 348.3 & 129.6 & 91.2 & 49.9 & 76.9 \\
Method A & ${ }^{\circ} \mathrm{C}$ & 85.38 & 85.38 & 85.38 & 85.38 & 102.02 & 101.70 \\
Method B & ${ }^{\circ} \mathrm{C}$ & 87.67 & 90.35 & 89.31 & 89.43 & 95.64 & 94.85 \\
\hline
\end{tabular}

The method $\mathrm{B}$ is fitted with the experimental data by the Holland scholar A.G.Okkes, considering the influence of the content of water vapor and $\mathrm{SO}_{3}$ in the flue gas on the acid dew-point temperature. Computational data is close to the experimental data, and can be used to evaluate the accuracy of other formulas [3]. Flue gas through the $\mathrm{SCR}$, due to the oxidation of the catalyst, part of $\mathrm{SO}_{2}$ will change to $\mathrm{SO}_{3}$, resulting in elevated $\mathrm{SO}_{3}$ content, resulting in increase of acid dew-point temperature, by $87.67^{\circ} \mathrm{C}$ increased to $90.35^{\circ} \mathrm{C}$, elevated $2.68^{\circ} \mathrm{C}$. Flue gas passes through the air-heater, part of the $\mathrm{SO}_{3}$ will occur acid condensation and steam sulfate coagulate easily in the air-heater surface adhesion of fly ash, and SCR system leakage of NH3 will react with $\mathrm{SO}_{3}$ generated ammonium hydrogen sulfate. Therefore, the $\mathrm{SO}_{3}$ content of the flue gas will be reduced accordingly. The test data also further verify this situation. The content of $\mathrm{SO}_{3}$ decreased from $5.6 \mu \mathrm{mol} / \mathrm{mol}$ in SCR outlet to $4.9 \mu \mathrm{mol} / \mathrm{mol}$ air heater outlet, the content of $\mathrm{SO}_{3}$ was decreased by $12.5 \%$. The dew-point temperature of the flue gas is also decreased by about $1{ }^{\circ} \mathrm{C}$. The gas passes through the electrostatic precipitator, because the $\mathrm{SO}_{3}$ is attached to the ash particles, will reduce the content of $\mathrm{SO}_{3}$, causing the acid dew-point temperature rise.

But the rise is small, only $0.12{ }^{\circ} \mathrm{C}$. This may be related to higher gas temperature. When the flue gas passes through the FGD, the humidity increases, will cause the acid dew-point temperature to rise, but the $\mathrm{SO}_{3}$ content decreases, can cause the acid dew-point temperature to decrease. The interaction between the two is offset. Acid dew-point temperature is increased from $89.43^{\circ} \mathrm{C}$ to $95.64^{\circ} \mathrm{C}$ by the combined effect.

In order to study the acid dew-point temperature of the gas with different sulfur content of coal, the conversion rate of $\mathrm{SO}_{2}$ was assumed to remain constant. The acid dew-point temperature is calculated by the A.G.Okkes formula, and the results are shown in Figure 1.

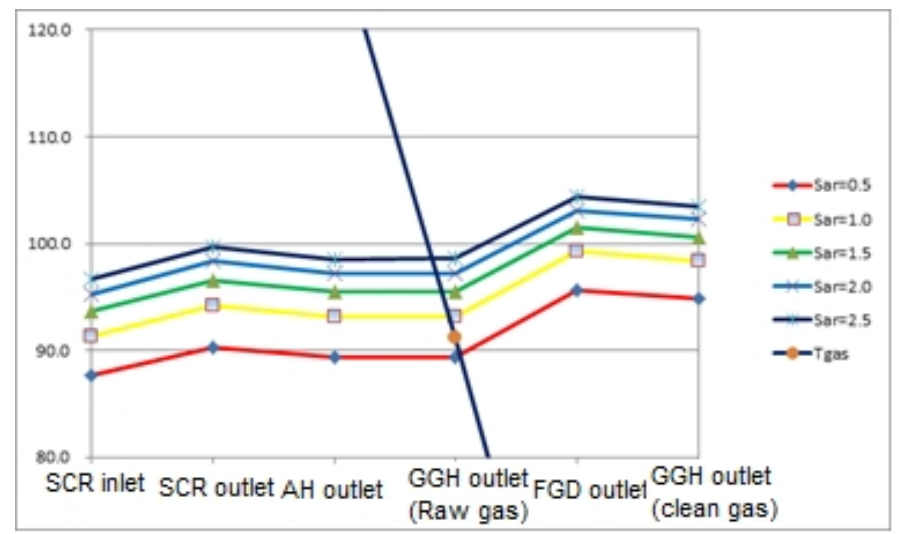

Figure 1. Comparison of the Dew-point Temperature of Different Sulfur Content Coal

From Figure 1 it can be seen that the dew-point temperature of the flue gas is gradually increased with the increase of the amount of coal, but the magnitude of the increase is gradually reduced. Flue gas through the SCR, due to the increase of $\mathrm{SO}_{3}$ content, the acid dew-point temperature will be a corresponding rise, rise about $3^{\circ} \mathrm{C}$; flue gas through the air preheater and electro precipitator, due to the decrease of $\mathrm{SO}_{3}$ content, acid dew-point temperature will decreased slightly, decreased by about $1{ }^{\circ} \mathrm{C}$. When the flue gas is absorbed by FGD, the flue gas acid dew-point temperature will have an obvious jump, and the amplitude is about $6^{\circ} \mathrm{C}$.

After GGH, the flue gas temperature can fall to the acid dew-point temperature, resulting in sulfuric acid corrosion. The highest value of flue gas acid dew-point temperature appeared in the FGD 
outlet section, the biggest deviation of acid dew-point temperature and gas temperature also appeared in this section. Therefore, it is also the most easy to form dilute sulfuric acid steam and cause corrosion.

\section{Measures to reduce the temperature of acid dew-point}

Reducing acid dew-point temperature has important significance for the protection of boiler equipment. Under the premise of burning coal, reducing the dew-point temperature can be achieved by decreasing the $\mathrm{SO}_{3}$ content. At present, there are two main methods to reduce the content of $\mathrm{SO}_{3}$.

\section{Absorbent injection technology}

To the inlet or the outlet of air heater jet lime, magnesium hydroxide and other alkaline substances, these substances can react with $\mathrm{SO}_{3}$ and remove it. The removal of $\mathrm{SO}_{3}$ is more complete, the removal efficiency[4] can reach $90 \%$, and the $\mathrm{SO}_{3}$ can be removed to a very low concentration $(<3 \mu \mathrm{mol} / \mathrm{mol})$. The utility model is especially suitable for burning high sulfur coal area.

\section{The denitration catalyst development of low $\mathrm{SO}_{2}$ oxidation rate}

The oxidation of $\mathrm{SO}_{2}$ in SCR system can increase the concentration of $\mathrm{SO}_{3}$, and the applacation of low oxidation rate catalyst can effectively reduce the formation of $\mathrm{SO}_{3}$. A important index of low $\mathrm{SO}_{2}$ oxidation rate is $\mathrm{KNOx} / \mathrm{KSOx}$, improve $\mathrm{KNOx} / \mathrm{KSOx}$ ratio to ensuring high DeNOx activity, the $\mathrm{SO}_{2}$ oxidation rate is controlled in a reasonable range at the same time, by adjusting the formula of catalyst, the catalyst wall thick, pore structure [5] to develop low $\mathrm{SO}_{2}$ oxidation rate of catalyst.

\section{Conclusions}

(1)According to standard method of boiler unit heat calculation, the influence factor of the dew-point temperature is mainly on the ash, sulfur content of coal and water vapor content of the gas. But this method cannot reflect the influence of the conversion of $\mathrm{SO}_{2}$ to $\mathrm{SO}_{3}$ on the the acid dew-point temperature of gas.

(2)The A.G.Okkes formula is derived from the experimental data, the formula considering the influence of the $\mathrm{SO}_{3}$ and $\mathrm{H} 2 \mathrm{O}$ content in flue gas on acid dew-point temperature. It's a relatively accurate method.

(3)When through the gas denitration system, due to the increase of $\mathrm{SO}_{3}$ content, the acid dew-point temperature will be a corresponding rise, and raised about $3^{\circ} \mathrm{C}$; through the air heater and electrostatic precipitator, due to the decrease of $\mathrm{SO}_{3}$ content, acid dew-point temperature will be decreased slightly and decreased about $1{ }^{\circ} \mathrm{C}$. When the gas is absorbed by the FGD, the acid dew-point temperature will have an obvious jump, and the amplitude is about $6^{\circ} \mathrm{C}$.

(4)Under the premise of burning coal, reducing the dew-point temperature can be achieved by reducing the $\mathrm{SO}_{3}$ concentration in the gas. At present, the main method to reduce the $\mathrm{SO}_{3}$ content is absorbent injection technology and denitration catalyst development of low $\mathrm{SO}_{2}$ oxidation rate.

\section{References:}

[1] Wu Zhongbiao, should Hong bin. Research on the conversion rate of coal and sulfur dioxide in power plant [J]. Chongqing environmental science,2011(2):35-36.

[2] Wei Hongge, Cheng Xuefeng, etc., the generation and conversion of $\mathrm{SO}_{3}$ in coal fired flue gas and its suppression strategy. [J]. industrial boiler, 2003 (6):31-35

[3] Li Pengfei, Tong Huiling. Calculation method of comparison and analysis of acid dew-point of flue gas. [J]. boiler technology, 2009 (11):5-8

[4] Hao Jimin, Ma Guangda. Air pollution control engineering [M]. Beijing: Higher Education Press, 2002:346-352

[5] Li Feng, Yu Chengzhi, Zhang Peng. Low $\mathrm{SO}_{2}$ oxidation denitration catalyst development [J]. electric power technology and environmental protection, 2010,4 (26): 18-21 